University of New Hampshire

University of New Hampshire Scholars' Repository

$12-14-2010$

\title{
Education, politics and opinions about climate change: Evidence for interaction effects
}

Lawrence C. Hamilton

University of New Hampshire, Durham, lawrence.hamilton@unh.edu

Follow this and additional works at: https://scholars.unh.edu/soc_facpub

Part of the Sociology Commons

\section{Comments}

This is the pre-peer reviewed version of the following article: Hamilton, L.C. 2011. "Education, politics and opinions about climate change: Evidence for interaction effects." Climatic Change 104:231-242, which has been published in final form at https://dx.doi.org/10.1007/s10584-010-9957-8. This article may be used for non-commercial purposes in accordance with Wiley Terms and Conditions for Self-Archiving.

\section{Recommended Citation}

Hamilton, L.C. 2011. "Education, politics and opinions about climate change: Evidence for interaction effects." Climatic Change 104:231-242. doi: 10.1007/s10584-010-9957-8

This Article is brought to you for free and open access by the Sociology at University of New Hampshire Scholars' Repository. It has been accepted for inclusion in Sociology Scholarship by an authorized administrator of University of New Hampshire Scholars' Repository. For more information, please contact Scholarly.Communication@unh.edu. 
AUTHOR'S DRAFT. Final version published in:

Climatic Change (2011) 104:231-242. doi: 10.1007/s10584-010-9957-8

\title{
EDUCATION, POLITICS AND OPINIONS ABOUT CLIMATE CHANGE EVIDENCE FOR INTERACTION EFFECTS
}

\author{
Lawrence C. Hamilton
}

Lawrence.Hamilton@unh.edu

Sociology Department

University of New Hampshire

Durham, NH 03824

\section{Keywords}

Public opinion, global warming, climate change, surveys, politics, ideology, education

\begin{abstract}
U.S. public opinion regarding climate change has become increasingly polarized in recent years, as partisan think tanks and others worked to recast an originally scientific topic into a political wedge issue. Nominally "scientific" arguments against taking anthropogenic climate change seriously have been publicized to reach informed but ideologically receptive audiences. Reflecting the success of such arguments, polls have noted that concern about climate change increased with education among Democrats, but decreased with education among Republicans. These observations lead to the hypothesis that there exist interaction (non-additive) effects between education or knowledge and political orientation, net of other background factors, in predicting public concern about climate change. Two regional telephone surveys, conducted in New Hampshire $(n=541)$ and Michigan $(n=1,008)$ in 2008, included identical climate-change questions that provide opportunities to test this hypothesis. Multivariate analysis of both surveys finds significant interactions. These empirical results fit with theoretical interpretations and several other recent studies. They suggest that the classically-identified social bases of concern about the environment in general, and climate in particular, have shifted in recent years. Narrowcast media, including the many Web sites devoted to discrediting climate-change concerns, provide ideal conduits for channeling contrarian arguments to an audience predisposed to believe and electronically spread them further. Active-response Web sites by climate scientists could prove critical to counterbalancing contrarian arguments.

\section{Acknowledgments}

This research has been supported by a grant from the Charles Stewart Mott Foundation, and by the Carsey Institute at the University of New Hampshire, with cooperation from the UNH Survey Center. David Moore, Cynthia M. Duncan, Chris Colocousis, Megan Henly and Andrew Smith contributed to the questionnaire designs. Riley Dunlap and other discussants at the American Sociological Association meetings provided helpful comments on an earlier draft.
\end{abstract}




\section{Introduction}

The accumulating scientific evidence about climate change appears, at first glance, not to have moved U.S. public opinion very far. Despite recent outbursts of media coverage regarding extreme weather, Arctic ice and endangered polar bears, along with the Fourth Assessment Report by the Intergovernmental Panel on Climate Change (IPCC 2007a-d) and the Oscarwinning film An Inconvenient Truth, surveys detect little rise in overall public concern (Newport 2008; Nisbet and Myers 2007). Americans rank global warming as a low priority (Pew 2007), with a majority believing it poses no threat in their lifetimes (Newport 2008). These patterns seem unusual not just for their contrast with the science and news headlines, but for their contrast with public opinion in other nations as well. The Pew Global Attitudes Project found that among people of 15 industrialized countries surveyed, only the Chinese expressed comparably low levels of concern (Pew 2006; also see Lorenzoni and Pidgeon 2006).

Apparent U.S. complacency masks two divergent trends. Public opinion has grown increasingly polarized along political or ideological lines, even while the average changed little. The percentage of Democrats agreeing that global warming has begun rose gradually over a tenyear period, from $47 \%$ in 1998 to $76 \%$ in 2008 . Over the same years the percentage among Republicans declined from 46 to 41\% (Dunlap and McCright 2008). By 2008, 59\% of Republicans, compared with only $18 \%$ of Democrats, believed that the seriousness of global warming was generally exaggerated in the news. Other polls have found similar results (e.g., Pew 2006).

The politicization of what was originally a scientific question has not been accidental. Polarization reflects the opposition between conservative campaigns promoting the views of a small number of "skeptical" or contrarian scientists to argue against greenhouse gas reductions, on the one hand (as documented by Jacques et al. 2008; McCright and Dunlap 2000, 2003; UCS 2007), and publications of the wider scientific consensus (such as the IPCC) supported by liberal and environmental activists (such as Al Gore, with An Inconvenient Truth) on the other. Contrarian arguments, although couched in nominally scientific terms (for example, regarding changes in polar ice sheets), largely bypassed the science processes of peer-reviewed journals and meeting presentations. Instead, they directly addressed policymakers and the issue-aware public through books, reports and editorials, supplying people with a choice of which "experts" to believe. If more educated audiences paid closer attention to the competing scientific claims, and selectively retained information that seemed to conform with their background beliefs, that could account for the opposite correlations observed between education and the climate-change views of conservatives and liberals.

Social scientists have a substantial literature concerning "the social bases of environmental concern"- - studies of demographic, ideological and other individual characteristics as predictors of concern about environmental problems. Recently, a number of authors have extended this tradition to study the social bases of concern about climate change or global warming (e.g., Dietz et al. 2005, 2007; Dunlap and McCright 2008; Finucane et al. 2000; Hamilton 2008; Hamilton and Keim 2009; Kahan et al. 2005; Krosnick et al. 2006; Wood and Vedlitz 2007).[1] The first-order poll findings about education and political orientation cited above suggest that in at least one important respect, the social bases of environmental concern could be changing. Education no longer has a simple positive effect on concern. 
This paper presents tests of non-additive or interaction hypotheses involving education (or information) and political orientation, drawing on two regional surveys conducted in 2008. Despite substantial differences between the locations, timing, content and goals of the two surveys, both show interaction effects.

\section{Data and Methods}

Data for this analysis come from two random-sample telephone surveys. The first is the Granite State Poll (GSP), a statewide survey of political and other opinions conducted quarterly by the University of New Hampshire's Survey Research Center. In January 2008, the Granite State Poll included several questions about global warming, in addition to its usual range of background and political-opinion items. The Granite State Poll achieves prominence every four

years during New Hampshire's presidential primary season, and employs standard, well-validated techniques for obtaining representative samples of the state's adult population.

The second data source is a survey of residents from five rural counties (Alger, Chippewa, Luce, Mackinac and Schoolcraft) on Michigan's Upper Peninsula, conducted in August 2008. The Michigan survey formed part of the Community and Environment in Rural America (CERA) project, a large-scale study of selected rural U.S. regions (Hamilton et al. 2008). Like the Granite State Poll, the Michigan CERA survey sought a representative sample of the adult population in its target area. Census age-sex-race tables for these five counties affirmed that sampling had been successful. For both surveys, probability weights permit minor adjustments for design and sampling bias, and have been applied to all analyses in this paper.

The New Hampshire and Michigan surveys had different content and goals, in addition to their geographically and socioeconomically disparate samples. The two surveys did, however, include two identical items about global warming, which had also been asked on a 2008 Gallup Poll. These items, understand and threat, appear at the top of Table 1. The table also lists definitions and responses to four background questions, similar enough across GSP and CERA to be used for comparison.[2] Confidence intervals are all less than $\pm 5 \%$.

$<<$ Table 1 about here $>>$

A majority of respondents on all three surveys said that they understood global warming "fairly well." More confident "very well" responses occurred most often in New Hampshire (33\% vs. $25 \%$ or $21 \%$; for comparison with historical Gallup results see Nisbet and Myers 2007:448). This could reflect the state's politically engaged (e.g., high voter turnout; see USEP 2009) and well-educated population. Fifty-two percent of the New Hampshire respondents reported having college degrees, compared with only $36 \%$ of the Upper-Peninsula Michigan respondents.

Despite high levels of self-assessed understanding among New Hampshire respondents, just $41 \%$ believed that global warming would pose a serious threat in their lifetime - similar to Gallup's 40\% national value, and well above that for Michigan (31\%). Design-weighted $F$ tests (not shown) found no significant relationship between understand and threat in either the New Hampshire or Michigan surveys, contrary to what climate researchers might hope.

The puzzling appearance of no relationship between understand and threat is clarified when we break it down politically, as done with the New Hampshire survey in Figure 1. Democratic or Democrat-leaning respondents (categories 1-3 of party) appear at top left in this 
graphic, with Republicans (categories 5-7 of party) at bottom left. Among Democrats, the better they think they understand the issue, the more likely they are to perceive warming as a threat. A weaker version of this pattern occurs among Independents. Among Republicans, however, the better they think they understand the issue, the less likely they are to perceive a threat. No Republican said they did not understand it at all. Sixty-four percent of the Democrats who understand "very well" see a threat, compared with just $14 \%$ of Republicans.

$<<$ Figure 1 about here $>>$

Self-assessed understanding, of course, is not the same as objectively-measured knowledge (Nisbet and Myers 2007). One analysis using quiz-based measures from the General Social Survey (GSS) found just simple positive effects of science knowledge on concern about climate-change impacts, unlike the more complicated effect of self-assessed understanding in Figure 1 (Hamilton 2008).

\section{Results}

In addition to political orientation, other social-positional factors have been widely shown as predictors of environmental concern (for a recent international example that cites earlier work, see Olofsson and Öhman 2006). The most consistent findings concern age (negatively related to concern) and education (positively related). Gender often proves important, but with less consistent effects. The analyses in this section include age and gender as control variables, statistically adjusting for those previously-known relationships as we examine interaction hypotheses involving education, "understanding" and political orientation.

Table 2 shows results from a weighted logit regression of threat (perceived threat of global warming) on the other variables listed in Table 1: gender, age, education, political party and self-assessed understanding of global warming. To test for interactions involving party, education and understand, these three variables were centered (re-expressed as mean deviations) and combined into the product terms education $\times$ party and understand $\times$ party. The jackknife standard errors and tests shown should be more conservative and robust than classical standard errors applied to these survey data.[3]

$<<$ Table 2 about here $>>$

Gender has a positive, significant effect: women more often thought that global warming posed a threat in their lifetime (for good discussions of gender effects on environmental-risk perceptions, see Davidson and Freudenburg 1996; Finucane et al. 2000; Kahan et al. 2005). Older respondents were less likely to see a threat, perhaps partly because their personal horizons extend less far into the 21 st century. Political party exerts a strong negative effect: as identification with the Republican party increases, respondents became less likely to believe that global warming posed a threat - consistent with other findings that individuals with conservative ideologies tend to discount anthropogenic climate change (Dietz et al. 2007; Dunlap and McCright 2008; Pew 2006, 2007).

Both surveys thus agree on the signs and significance of gender, age and party effects, and also on the nonsignificance of main effects for education. We see divergent patterns with regard to the education $\times$ party and understand $\times$ party interactions. Among New Hampshire respondents, understand $\times$ party has a significant effect. Among Michigan respondents, education $\times$ party has a significant effect. It is worth noting that whether significant or not, both 
interactions in both surveys exhibit the expected negative signs. Moreover, $F$ tests (not shown) for each survey's pair of interaction effects (education $\times$ party and understand $\times$ party both) reject the null hypothesis.

The New Hampshire results serve to illustrate interpretation of such effects. The main effect of understand is .235. Because education, party and understand all were centered before generating the interaction terms, we can interpret this as the positive effect (increased log odds of seeing warming as a threat) of a one-unit increase in understanding, for respondents of average political party identification. Along with reduced multicollinearity, straightforward interpretation of main effects is the chief benefit of centering in this context.[4]

The coefficient on understand $\times$ party is -.203 . Thus, for respondents who identify themselves as strong Democrats (party $=1$, or as a mean deviation $1-3.7=-2.7$ ), the $\log$ odds that global warming is perceived as a threat increase by .783 with each one-unit increase in selfreported understanding:

$$
.235+(-2.7 \times-.203)=.783
$$

On the other hand, for respondents who identify themselves as strong Republicans (party $=7$, or as a mean deviation $7-3.7=3.3$ ), the log odds that warming is perceived as a threat decrease by .435 with each additional unit of self-reported understanding:

$$
.235+(3.3 \times-.203)=-.435
$$

In other words, Democrats who believe they understand global warming better also are more likely to believe that it poses a threat in their lifetimes. Conversely, Republicans who believe they understand global warming better are less likely to believe that it poses a threat. Ideology thus affects perceptions of the science behind climate change. The conditional effects plot in Figure 2 re-expresses logit coefficients in the more intuitive metric of probabilities. It graphs the effect of understand on threat for extreme values of party, with other variables set at their means.

$<<$ Figure 2 about here $>>$

In the Michigan survey an understand $\times$ party interaction was not a significant predictor, but education $\times$ party was. This interaction has a similar flavor, as seen in Figure 3 . The probability of perceiving global warming as a threat increases with education among Democrats, but decreases with education among Republicans. Only two respondents out of a thousand described themselves as "strong Democrats" or "strong Republicans" with less than an 8th grade education, so the crossover at far left in Figure 3 should not be over-interpreted. Setting aside this extreme, threat perceptions are roughly similar among Republicans and Democrats with lower education. They are most divergent among those with higher educations.

$<<$ Figure 3 about here $>>$

\section{Discussion}

Our data are regional, but these findings have broad implications. First, they are supported by other results. The education $\times$ party interaction found among Michigan respondents agrees with findings from several national polls (Pew 2006; Dunlap and McCright 2008). Similar interaction effects have been reported with respect to concern about polar aspects of climate change, using the 2006 General Social Survey (Hamilton 2008). Analysis of the 2007 CERA survey in rural areas of nine U.S. states likewise found an interaction affecting perceived 
local effects of climate change (Hamilton and Keim 2009). Other CERA questions on localenvironment (but not climate related) topics showed interaction effects as well (Hamilton et al. in review). Table 3 summarizes replications involving four different surveys and nine dependent variables. Those nine variables are the main ones analyzed in each paper (or four of six analyzed in Hamilton 2008). That is, they were not selected because of interaction patterns.

$<<$ Table 3 about here $>>$

Secondly, the education $\times$ party and similar interactions are both socially and climatically important. Earlier researchers found education (along with age) to be the most consistent predictor of citizen concern about the environment, and about climate in particular. Tables 2 and 3 indicate that this has changed. Although age effects remain evident, education now shows inconsistent effects depending on political orientation (Figure 3). The inconsistency marks a social shift away from patterns seen in older research. It reflects the efficacy of media campaigns that provide scientific-sounding arguments against taking climate change seriously, which disproportionately reach educated but ideologically receptive audiences (Freudenburg 2000; Jaques et al. 2008; McCright and Dunlap 2000, 2003; UCS 2007). Among many educated, conservative citizens, it appears that that such arguments have overshadowed the scientific consensus presented by the IPCC reports and other core science sources.

Ideological predispositions can affect how people process information (Shwom et al. 2008; Wood and Vedlitz 2007). The Internet and cable television news make it easier for us not only to process information selectively ourselves, but to selectively acquire information that has been processed already, when we only tune in to ideologically-compatible Web sites, cable news shows and so forth (Iyengar and Hahn 2007; Pew 2004). The bias or selectivity of our sources can be higher than the newspapers, magazines or broadcast news that formerly supplied most current-events information. Narrowcast media, including many Web sites devoted to discrediting climate-change concerns, provide ideal conduits for channeling politically inspired but scientific sounding arguments to an audience predisposed to retain and repeat them. The power to repeat favored arguments has been vastly expanded as well, through forwarding emails or posting links and content online, in a process that can become "viral" as it motivates new readers to do the same. The pace of normal scientific communication is glacial by comparison.

The effective dissemination of contrarian arguments means that many people who have no contact with climate scientists or the primary research literature can nevertheless learn that a scientist says temperatures have risen on Mars (politically spun as evidence that global warming has solar or cosmic origins), or another scientist says it is cooling in East Antarctica (spun as evidence that our planet is not warming after all). They might consider themselves well informed about climate science even while not understanding its basic ideas - as evident in Figures 1 and 2. Lack of knowledge concerning the scientific context of Mars and Antarctica reports, or lack of consistency between the lessons political commentators might draw from them, need not be an obstacle to accepting and repeating those lessons when they fit with pre-existing beliefs.

If non-specialists want to find out what scientists really know about temperature trends of Mars and East Antarctica, or other arguments aired in today's news or last night's party, they are best served by a relatively small number of active-response Web sites written by climate scientists, such as Realclimate.org. Unlike journal articles, science meetings or reports, Web sites and blogs have the capability to react quickly (albeit less rigorously), reach broader 
audiences, and seriously confront arguments that have no scientific merit. Moreover, their online science posts can be passed on from reader to reader, which is difficult to do with journal articles or technical reports. The hard work that climate scientists invest in these sites could thus play a critical role in disseminating solid information about climate to educated and ideologically receptive audiences, counterbalancing those reached so successfully by the "climate change is a hoax" campaigns. 


\section{Notes}

[1] Scientists often prefer to discuss "climate change" rather than "global warming," because the former term better expresses the complexity of shifts that could include regional cooling despite average warming, as well as other changes in seasonality, variability or extreme events. In public discourse, however, the terms tend to be used interchangeably, with "global warming" more common - as on most surveys.

[2] Other studies, including those in Table 3, often consider race among the background predictors. The New Hampshire and rural Michigan samples are relatively homogeneous in that respect, however. The simple 7-point scale for political party preference has proven useful on political opinion polls, including many connected with the 2008 presidential election. A more nuanced review of the ideological dimensions of public support for environmental protection appears in Dunlap et al. (2001).

[3] Jackknife estimation involves resampling the data $n$ times, each time leaving out one observation (or in complex surveys, one primary sampling unit). This procedure yields alternative design-based standard errors for hypothesis tests and confidence intervals, with less reliance on theoretical assumptions (StataCorp 2007; also see Hamilton 2009). For both models in Table 2, jackknife estimation produced slightly larger, more conservative standard errors (hence, lower $t$ or $F$ statistics and higher $p$ values) than those calculated from theory.

[4] OLS variance inflation factors (VIF) were calculated as a check for possible multicollinearity problems involving the predictors in Table 2. The highest VIFs were 1.08 (New Hampshire data) or 1.16 (Michigan data). Values above 10 would be cause for concern; see Chatterjee et al. (2000). 


\section{References}

Chatterjee, S., A.S. Hadi and B. Price (2000) Regression Analysis by Example, 3rd edition. New York: John Wiley \& Sons.

Davidson, D.J. and W.R. Freudenburg (1996) Gender and environmental risk concerns: A review and analysis of available research. Environment and Behavior 28:302-339.

Dietz, T., A. Fitzgerald and R. Shwom (2005) Environmental values. Annual Review of Environment and Resources 30:335-374.

Dietz, T., A. Dan and R. Shwom (2007) Support for climate change policy: Social psychological and social structural influences. Rural Sociology 72:185-214.

Dunlap, R.E., C. Xiao and A.M. McCright (2001) Politics and environment in America: Partisan and ideological cleavages in public support for environmentalism. Environmental Politics 10(4):23-48.

Dunlap, R.E. and A.M. McCright (2008). A widening gap: Republican and Democratic views on climate change. Environment September/October http://www.environmentmagazine.org/Archives/Back\%20Issues/September-October\%202008/du nlap-full.html

Finucane, M.L., P. Slovic, C,K. Mertz, J. Flynn and T.A. Satterfield (2000) Gender, race, and perceived risk: The 'white male' effect. Health, Risk and Society 2(2):159-172.

Freudenburg, W.R. (2000) Social constructions and social constrictions: Toward analyzing the social construction of 'the naturalized'as well as 'the natural.' Pp. 103-119 in G. Spaargaren, A.P.J. Mol and F.H. Buttel (eds.), Environment and Global Modernity. London: Sage.

Hamilton, L.C. (2008) Who cares about polar regions? Results from a survey of U.S. public opinion. Arctic, Antarctic, and Alpine Research. 40(4):671-678.

Hamilton, L.C. (2009) Statistics with Stata, version 10. Belmont, CA: Cengage.

Hamilton, L.C. and B. Keim (2009) Regional variation in perceptions about climate change. International Journal of Climatology doi: 10.1002/joc.1930

Hamilton, L.C., L.R. Hamilton, C.M. Duncan and C.R. Colocousis (2008) Place Matters: Challenges and Opportunities in Four Rural Americas. Durham, NH: Carsey Institute, University of New Hampshire. 
Hamilton, L.C., C.R. Colocousis and C.M. Duncan (in review). Place effects on environmental views.

IPCC (2007a) Climate Change 2007 - The Physical Science Basis. Contribution of Working Group I to the Fourth Assessment Report of the Intergovernmental Panel on Climate Change. Cambridge: Cambridge University Press.

IPCC (2007b) Climate Change 2007 - Impacts, Adaptation and Vulnerability. Contribution of Working Group II to the Fourth Assessment Report of the Intergovernmental Panel on Climate Change. Cambridge: Cambridge University Press.

IPCC (2007c) Climate Change 2007 - Mitigation of Climate Change. Contribution of Working Group III to the Fourth Assessment Report of the Intergovernmental Panel on Climate Change. Cambridge: Cambridge University Press.

IPCC (2007d) Climate Change 2007 — Synthesis Report. Cambridge: Cambridge University Press.

Iyengar, S. and Hahn, K. S. (2007) Red media, blue media: Evidence of ideological polarization in media use. Paper presented at the annual meeting of the International Communication Association, San Francisco, CA, 5/23/07.

Jacques, P.J., R.E. Dunlap and M. Freeman (2008) The organisation of denial: Conservative think tanks and environmental scepticism. Environmental Politics 17(3):349-385.

Kahan, D.M., D. Braman, J. Gastil, P. Slovic and C.K. Mertz (2005) Gender, race and risk perception: The influence of cultural status anxiety. New Haven, CT: Public Law \& Legal Theory Research Paper No. 86.

Krosnick, J.A., A.L. Holbrook, L. Lowe and P.S. Visser (2006) The origins and consequences of democratic citizens' policy agendas: A study of popular concern about global warming. Climatic Change doi: 10.1007/s10584-006-9068-S.

Lorenzoni I. and N.F. Pidgeon (2006) Public views on climate change: European and USA perspectives. Climatic Change 77(1-2):73-95.

McCright, A.M. and R.E. Dunlap (2000) Challenging global warming as a problem: An analysis of the conservative movement's counter-claims. Social Problems 50(3):348-373.

McCright, A.M. and R.E. Dunlap (2003) Defeating Kyoto: The conservative movement's impact on the U.S. climate change policy. http://stephenschneider.stanford.edu/Publications/PDF_Papers/McCrightDunlap2003.pdf accessed 6/25/2008. 
Newport, F. (2008) Little increase in Americans' global warming worries. Gallup, http://www.gallup.com/poll/106660/Little-Increase-Americans-Global-Warming-Worries.aspx, accessed 6/26/2008.

Nisbet, M.C. and T. Myers (2007) Twenty years of public opinion about global warming. Public Opinion Quarterly 71(3):444-470.

Olofsson, A. and S. Öhman (2006) General beliefs and environmental concern: Transatlantic comparisons. Environment and Behavior 38:768-790.

Pew (2004) News audiences increasingly politicized: Online news audience larger, more diverse. Pew Research Center, June 8.

http://people-press.org/report/215/news-audiences-increasingly-politicized accessed 8/20/2009.

Pew (2006) Little consensus on global warming: Partisanship drives opinion. Pew Research Center, July 12. http://people-press.org/reports/display.php3?ReportID $=280$ accessed $11 / 17 / 2007$.

Pew (2007) Global warming: A divide on causes and solutions. Pew Research Center, January 24. http://people-press.org/reports/pdf/303.pdf accessed on December 14, 2007.

Shwom, R., A. Dan and T. Dietz (2008) The effects of information and state of residence on climate change policy preferences. Climatic Change 90:343-358.

StataCorp (2007) Stata Survey Data Reference Manual. College Station, TX: Stata Press.

UCS (2007) Smoke, Mirrors and Hot Air: How ExxonMobil Uses Big Tobacco's Tactics toManufacture Uncertainty about Climate Science. Cambridge, MA: Union of Concerned Scientists: Cambridge.

USEP (2009) United States Election Project. http://elections.gmu.edu/voter turnout.htm accessed on August 282009.

Wood, B.D. and A. Vedlitz (2007) Issue definition, information processing, and the politics of global warming. American Journal of Political Science 51(3):552-568. 
Table 1: Definitions of variables, with weighted summaries of responses to the Granite State Poll (GSP) survey of New Hampshire residents conducted in January $2008(n=541)$, and the Community and Environment in Rural America (CERA) survey of Upper Peninsula, Michigan residents conducted in August $2008(n=1008)$. Responses to similar global-warming questions on a Gallup poll of U.S. adults in March 2008 are shown for comparison (from Newport 2008).

understand - "Next, thinking about the issue of global warming, sometimes called the 'greenhouse effect,' how well do you feel you understand this issue - would you say very well, fairly well, not very well, or not at all?"

$1 \mathrm{DK} /$ Not at all

2 Not very well

3 Fairly well

4 Very well

\section{$\underline{\text { New Hampshire (GSP) }}$}

$3 \%$

$13 \%$

$51 \%$

$33 \%$

\begin{tabular}{cll} 
Upper Michigan (CERA) & & US (Gallup) \\
\cline { 1 - 2 } $3 \%$ & $10 \%$ \\
$16 \%$ & $10 \%$ \\
$56 \%$ & $59 \%$ \\
$25 \%$ & $21 \%$
\end{tabular}

threat - "Do you think that global warming will pose a serious threat to you or your way of life in your lifetime, or not?"

$\begin{array}{llll}0 \text { No } & 54 \% & 64 \% & 58 \% \\ 1 \text { Yes } & 41 \% & 31 \% & 40 \% \\ \text {. DK } & 5 \% & 5 \% & 2 \%\end{array}$

gender

$\begin{array}{lll}0 \text { Male } & 48 \% & 49 \%\end{array}$

1 Female $\quad 52 \% \quad 51 \%$

age — "What is your current age?" (means)

$52.2 \quad 48.1$

education - "What is the highest grade in school, or level of education that you've completed and got credit for?" (CERA used a 7-category scale, combined into 4 categories for this table.)

1 High school or less $\quad 24 \% \quad 32 \%$

2 Tech. school/some college $\quad 23 \% \quad 30 \%$

3 College graduate $\quad 32 \% \quad 24 \%$

4 Postgraduate work $\quad 20 \% \quad 12 \%$

. no answer $1 \% \quad 3 \%$

party - "Generally speaking, do you usually think of yourself as a Democrat, a Republican, an Independent or what?"

$\begin{array}{lll}1 \text { Strong Democrat } & 21 \% & 15 \% \\ 2 \text { Not very strong Democrat } & 9 \% & 11 \% \\ 3 \text { Independent, closer Dem. } & 19 \% & 12 \% \\ 4 \text { Independent - closer neither } & 18 \% & 18 \% \\ 5 \text { Independent, closer Rep. } & 11 \% & 9 \% \\ 6 \text { Not very strong Republican } & 7 \% & 11 \% \\ 7 \text { Strong Republican } & 16 \% & 13 \% \\ \text {. other, no answer } & 0 \% & 11 \%\end{array}$


Table 2: Will global warming be a serious threat in your lifetime? Weighted logit regressions of perceived threat on background factors, self-assessed understanding and interaction terms, with jackknife standard errors and tests. Variable definitions are shown in Table 1. For this analysis, education, party and understand were centered as mean deviations.

\begin{tabular}{|c|c|c|c|c|c|c|}
\hline \multirow[b]{2}{*}{ Predictors } & \multicolumn{3}{|c|}{ New Hampshire (GSP) } & \multicolumn{3}{|c|}{ Upper Michigan (CERA) } \\
\hline & Coef. & SE & $p(z)$ & Coef. & SE & $p(z)$ \\
\hline gender (female) & .974 & .232 & .000 & 699 & .234 & .003 \\
\hline age in years & -.031 & .008 & .000 & -.023 & .008 & .003 \\
\hline education & .144 & .112 & .197 & -.092 & .082 & .261 \\
\hline party (Republican) & -.266 & .060 & .000 & -.211 & .061 & .001 \\
\hline education $\times$ party & -.035 & .056 & .529 & -.097 & .041 & .018 \\
\hline understand GW & .235 & .154 & .128 & .537 & .172 & .002 \\
\hline understand $\times$ party & -.203 & .081 & .012 & -.097 & .089 & .274 \\
\hline constant & .685 & .423 & .106 & -.103 & .466 & .824 \\
\hline
\end{tabular}

$$
n=525 ; F(7,518)=7.96, p<.001 \quad n=895 ; F(7,884)=6.93, p<.001
$$


Table 3: Significant education $\times$ party (or similar) interaction effects have been found with global warming and other environmental questions on five recent surveys.

\begin{tabular}{|c|c|c|c|}
\hline Interaction & Dependent variables & Survey & Reference \\
\hline Education $\times$ conservative & $\begin{array}{l}\text { 1. sea level rise } \\
\text { 2. melting icecaps } \\
\text { 3. polar bears extinct } \\
\text { 4. Arctic seals threatened }\end{array}$ & 2006 national GSS & Hamilton 2008, $A A A R$ \\
\hline Education $\times$ political party & 5. local effects GW & 2007 9-state CERA & $\begin{array}{l}\text { Hamilton \& Keim 2009, } \\
\text { IJOC }\end{array}$ \\
\hline Education $\times$ political party & $\begin{array}{l}\text { 6. urban sprawl impacts } \\
\text { 7. conserve resources } \\
\text { 8. environmental rules good }\end{array}$ & 2007 9-state CERA & $\begin{array}{l}\text { Hamilton, Colocousis \& } \\
\text { Duncan forth., } R S\end{array}$ \\
\hline Education $\times$ political party & 9. threat of GW & 2008 MI CERA & Hamilton forth, $C C$ \\
\hline $\begin{array}{l}\text { Understand } \mathrm{GW} \times \text { political } \\
\text { party }\end{array}$ & 9. threat of GW & 2008 NH GSP & Hamilton forth, $C C$ \\
\hline
\end{tabular}




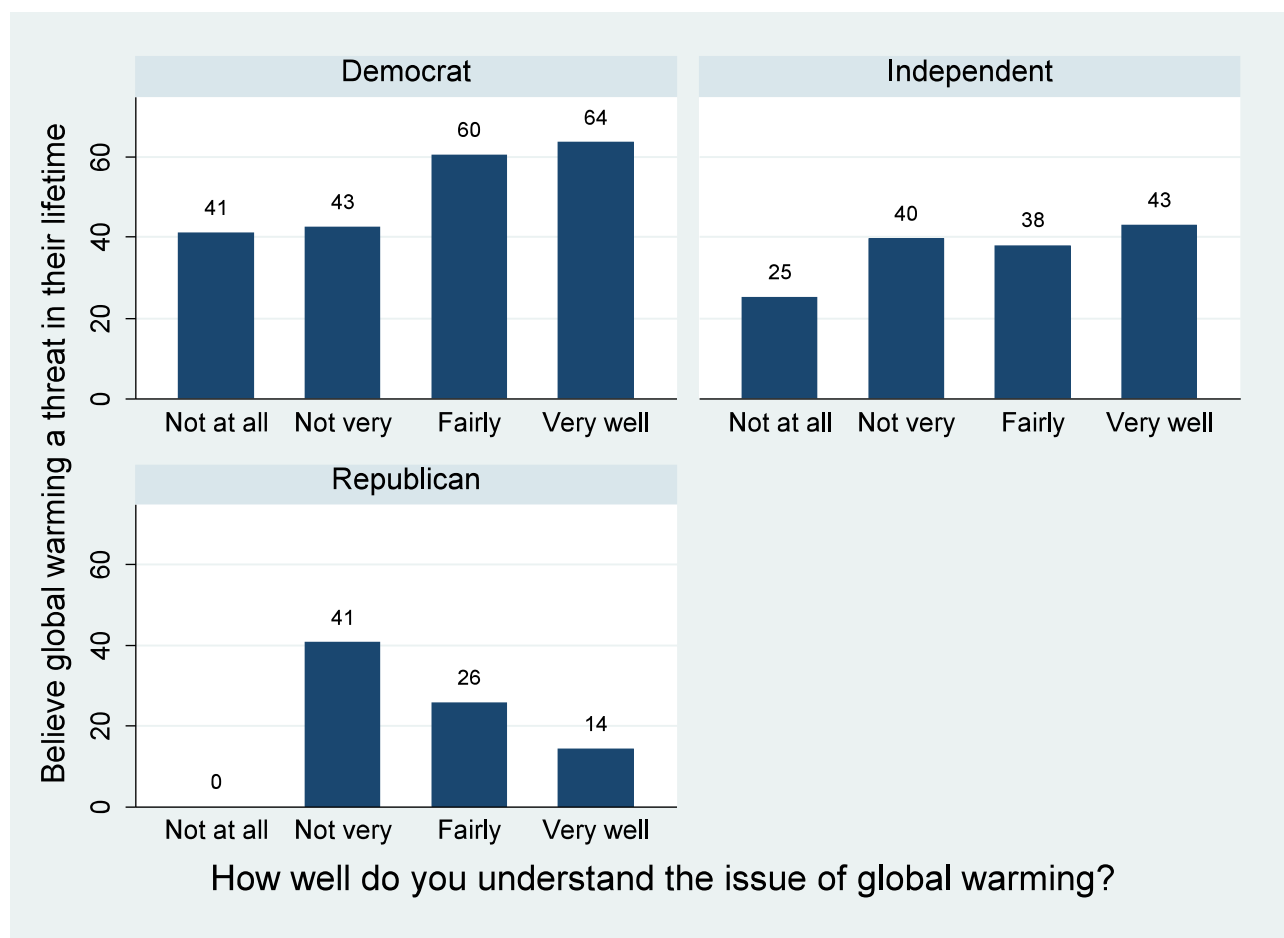

Figure 1: Weighted percent of New Hampshire respondents reporting they think that global warming will pose a serious threat in their lifetime (threat), by self-assessed understanding of the issue (understand) and political party identification (simplified from party). 


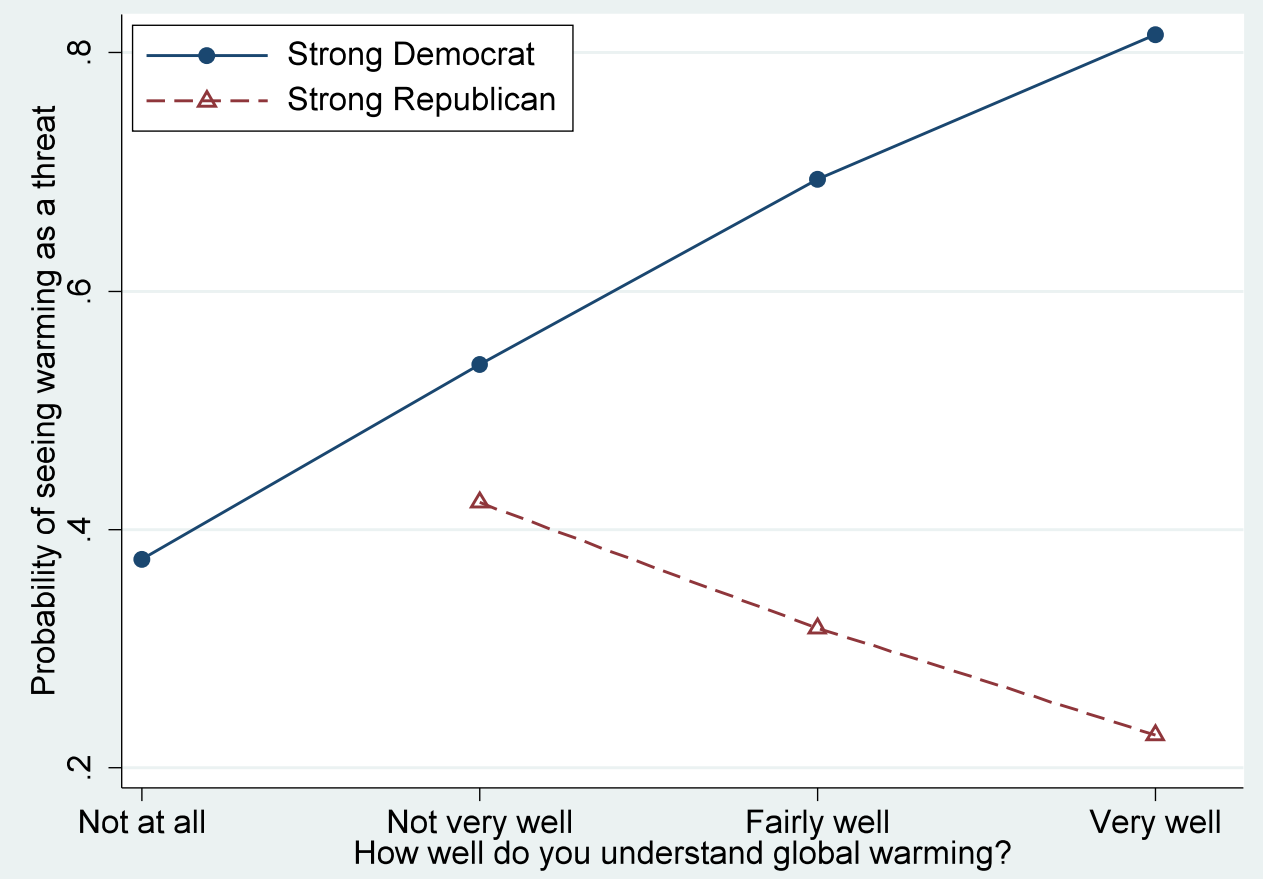

Figure 2: Predicted probability that New Hampshire residents believe that global warming will pose a serious threat vs. self-assessed understanding of the issue, for "strong Democrats" and "strong Republicans" (calculated from the first logit model in Table 2, setting other predictors at means). 


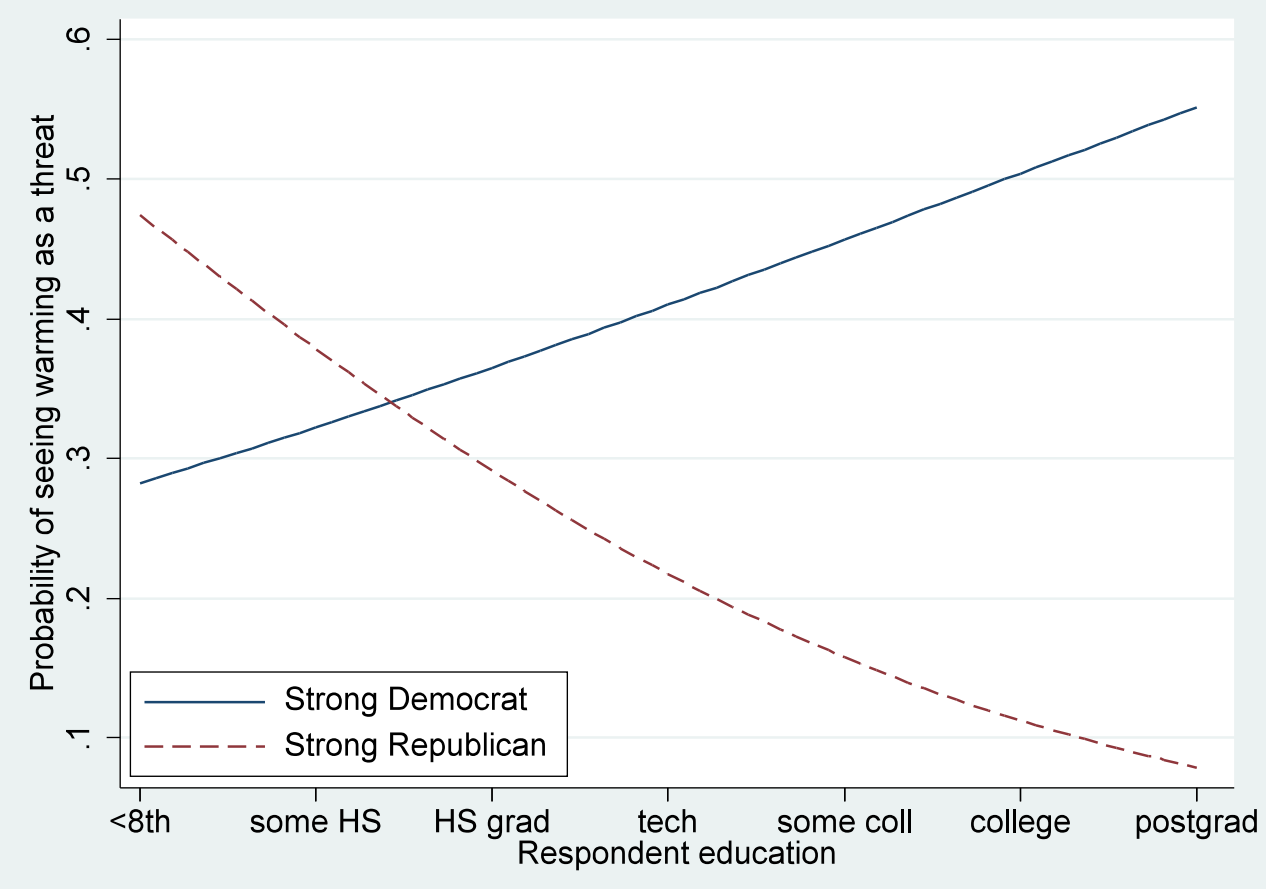

Figure 3: Predicted probability that Upper-Peninsula Michigan residents believe that global warming will pose a serious threat vs. respondent education, for "strong Democrats" and "strong Republicans" (calculated from the second logit model in Table 2, setting other predictors at means). 